The Edinburgh Companion to Atlantic Literary Studies. Ed. Leslie Eckel and Clare Elliott. Edinburgh: Edinburgh University Press, 2016; New York: Oxford University Press, 2016. ISBN: 9781474402941

\title{
Chapter 23 Transatlantic Magazines and the Rise of Environmental Journalism
}

\section{Susan Oliver, University of Essex.}

How did early nineteenth-century interest in science, travel and exploration shape the ways in which magazines in North America and Britain represented the natural environment? To what extent did periodicals contribute to the growth of armchair tourism and a public desire to encounter, through reading, a world beyond urban and metropolitan lifestyles? What difference did newspapers and magazines make to the way people thought about the natural world? This chapter investigates the emergence during the long nineteenth century of a culture of environmental journalism, paying attention to different kinds of writing that reflected progressive debates about botany, wilderness, land-use change, and aesthetics. The focus is on the development of a transatlantic environmental imaginary not constrained by (although it may have acknowledged or assented to the growth of) national interests. Then as now, environmental journalism was far from being a unified genre. Rather, it comprised a more or less thematically connected set of writings that operated across a range of different kinds of publication. Newspapers, magazines, special interest and professional journals, some with extravagant illustrations and others with little or no graphic content, provided a multimedial network through which ideas about natural science, domestic landscapes, pastoralism, and wilderness were shared and discussed.

Where visual imagery is concerned, photography needs special mention. Mass reproduction in the press of photographic images did not become commercially viable until the development of the rotogravure process in the 1880s. Yet photography made an 
immediate impact on environmental journalism; Louis Daguerre in France and William Henry Fox Talbot in Britain respectively made the daguerreotype and calotype processes publicly available at the beginning of 1839 . Editors of periodicals quickly employed teams of wood and steel-plate engravers, as well as lithographers, to reproduce the new 'heliographic drawings' or 'sun pictures,' as they were called, drawing attention to what was perceived as the more authentic detail provided by the 'pencil of nature' in comparison with the compositional agency of the artist.

The first published photographic images in the periodical press were botanical photographs and photomicrographs. On 20 April 1839, the cover of the London weekly Mirror of Literature, Amusement, and Instruction featured a woodcut facsimile of a photograph of a fern leaf, publicising its serialisation of Golding Bird's essay originally published in The Magazine of Natural History titled 'Observations on the Application of Heliographic or Photogenic Drawing to Botanical Purpose.' Each copy of Henry Fox Talbot's serially published The Pencil of Nature (1844) also included a calotype of a fern leaf, drawing readers' attention to photography's ability to combine beauty with attention to the anatomical detail of natural forms. ${ }^{\mathrm{i}}$ The London-based monthly Stereoscopic Magazine (1858-1865), owned and edited by Lovell Reeve, soon moved on to circulate threedimensional imagery in the form of stereographs inserted into each copy, alongside essays commenting on the subject matter and situating it in Darwinian scientific and British Imperial contexts. The plates included tropical plants at Kew Gardens, collections of Pacific seashells, corals, fossils, taxidermic reptiles from the British Museum, tree ferns in Tasmania and botanical micrographs. One of the few hand-tinted plates in the Stereoscopic was of the asafoetida plant from India, whose bright green leaves and emphasised petioles contributed an aesthetic based in the vitality of the growing plant, rather than in its more usual manifestation as a ground spice. Specially adapted stereoscopic viewers enabled readers to 
see the images in their three-dimensional form. Meanwhile, other publications had already anticipated motion cinematography. Thomas Wakley, editor of The Lancet, had set out his intention in 1830 to produce 'a moving picture of every interesting fact that may present itself to the notice of our reporters. ${ }^{\text {ii }}$ While such an aim extends the encyclopedic imaginary and scientific curiosity of the Enlightenment, it also identifies editors as technological visionaries alongside journalists as agents of modernity: reporters are explorers, gathering facts for editors to assemble into an experimental narrative. Always a professional medical journal that circulated in Britain and North America to discuss the latest discoveries in the classification, diagnosis and treatment of disease, the early Lancet promoted awareness of the human body within a wider context of natural science that qualifies its content as environmental journalism.

While there are clearly differences in style and focus according to the kind of publication and target audience, an intricate network can be traced in the responses and reactions that crossed and re-crossed class and educational boundaries as well as the Atlantic Ocean. Writing by male and female authors reveals gendered perspectives that do not always conform to cultural stereotypes of feminised land discovered, catalogued and cultivated by male improvers. Some environmental journalism consequently acquires a progressive social edge. For example, the many reviews of Helen Maria Williams's translations into English of Alexander von Humboldt's account of his and Aimé Bonpland's travels in the New World publicised the agency of a woman translator in circulating knowledge about natural science. While women routinely worked as translators within the nineteenth-century periodical industry, their contribution largely remained unacknowledged. Williams was already an established novelist, poet, travel writer and essayist. Her political affiliation with Girondiste circles during the early French revolutionary years, along with her unconventional lifestyle, meant that she was well-known by the time that she worked with Humboldt. 
Reviews of women's travel writing made available female perspectives on the natural world while also drawing attention to the political and social implications of those authors' activities. In the late 1790 s the Monthly Review censured Williams's concern with politics in her comparison of Switzerland with revolutionary Paris in A Tour in Switzerland (1798), while approving the more subtle political message embedded in her attention to landscape. iii The Monthly's conventional interpolation of loco-descriptive passages from Williams about the affective properties of avalanches, cataracts, torrents, crags, forests and ice fields that 'swelled the heart,' all termed 'digressions' by the reviewer, is followed by an extract from her Tour about environmental destruction. Near to Wassen, 'the industry of man' is noted by Williams to have given rise to 'sawing mills and other machinery' that consume water and trees. ${ }^{\text {iv }}$ This depiction of industrial development of the kind often identified as the beginnings of the Anthropocene, and which Ashton Nichols has termed 'urbannatural' on account of its transference of factory processes into the rural world, is about 'eating' trees in more ways than those immediately acknowledged; for timber and coal would have heated the water that produced the steam for the mill. ${ }^{\mathrm{v}}$ Williams's attention to the impact of factory forestry, seen through a Romantic lens and expressed using a discourse of sensibility, shows concern about the loss of a natural world that is as essential to intellectual thought as to a context beyond the human. The sawmill and an avalanche on a mountain stripped of trees are interpretable as allegories of anti-revolutionary repression and its consequences, including the Year of Terror in France, but both nevertheless draw attention to the loss of an ecological balance between humans as a privileged species and the rest of nature.

Other environmental journalism by women included thousands of reviews of poetry and prose, alongside articles often of a more everyday kind. Transcendentalist and journalist Margaret Fuller wrote about the changing landscape of the American Midwest for audiences across Europe as well as in North America. Fuller's widely reviewed book Summer on the 
Lakes, in 1843 observes how prairie plants were threatened by European invasive species, just as indigenous people were being removed from their homelands under the 1830 Indian Removal Act. Her attention to the common name 'white man's footprint' for the invasive European plantain that was moving westward in step with wheat farming emphasises an aggressive colonialism that combined human and natural self-interest. As Lance Newman, referring to Annette Kolodny, further points out, Summer on the Lakes places the alienation experienced by pioneer women on the prairies beyond a "deceptive "domestic fantasy" in which homestead farming in harmony with the land was given a promotional gloss. ${ }^{\mathrm{vi}}$ Editor for The Dial and for Horace Greeley's New-York Tribune newspaper, a close friend and correspondent of Scottish writers Thomas and Jane Carlyle, and a prominent pan-European travelling journalist, Fuller addressed a wide transatlantic audience with her accounts of landscapes in the process of alteration through species loss alongside human displacement.

The significance of less well known women writers risks underestimation because their many letters and articles for newspapers and magazines are more difficult to trace. These women created networks of curiosity and understanding that circulated ideas about nature and the environment through the medium of the press. As Libby Bischof has shown, towards the end of the nineteenth century The Women's Rest Tour Association of Boston encouraged independent transatlantic travel for women, especially to Britain, in ways that afforded physical and intellectual freedom without male companionship. ${ }^{\text {vii }}$ That liberty involved botanical and geological walking tours in addition to railway travel in remoter parts of Scotland, Wales and Ireland, with the experience of participants shared through the letters pages and articles in popular magazines. Scottish travel writer, journalist and explorer Isabella Bird's book A Lady's Life in the Rocky Mountains (1873) brought the landscapes and ecology of the American West to readers through accounts of the everyday experiences of the author during her visit to Colorado, then still a territory outside the Union. The many reviews 
of her book on both sides of the Atlantic increased public awareness of Bird's work as a woman explorer and naturalist. In 1891 she became the first woman to be elected Fellow of the Royal Geographical Society.

From the peripatetic essays of Henry David Thoreau, including 'Ktaadn,' published in the Union Magazine of Literature and Art in 1848 and later included in the three-essay volume The Maine Woods (1864), to the London-based Stereoscopic Magazine's use of photography, and through the many essays on the American West and Alaska published by Scottish emigrant John Muir during the last quarter of the nineteenth century, periodical culture responded to and stimulated interest in people's relationships with the non-human environment. The range of publication gave variety to the way that the reading public imagined the world beyond their immediate lives. In consequence, canonical authors who have long been understood to shape thinking about wilderness and 'nature' need to be read comparatively alongside a more everyday kind of writing, much of which was published anonymously but had immediate relevance to readers' experiences.

Issues of definition

The term 'environmental journalism' needs some explanation because the genre did not exist in any self-conscious form until the later nineteenth century. Scottish critic Fiona Campbell identifies the interpretive arbitrariness and intentionality that has always informed such writing on both sides of the Atlantic: 'essentially, environmental news is a version of "interpreted" environmental information . . . by the people who use it . . journalists, editors etc. ${ }^{\text {viii }}$ North American journalist and theorist Michael Frome traces the development of the modern environmental press through essays published by writers including Ralph Waldo Emerson, Henry David Thoreau, John Muir and George Perkins Marsh (sometimes called the 
'father of ecology'), while drawing attention to the rift that often separates such writing from environmental activism because of editorial policies aimed at accommodating commercial interests. ${ }^{\mathrm{ix}}$ Frome focuses on the impossibility of impartial commercial journalism, citing Saul Alinsky's argument that 'all life is partisan. There is no dispassionate objectivity.' Indeed, since the major newspapers and periodicals of the early nineteenth century were all printed on paper produced from wood pulp, then published and distributed from large towns and cities, the connection between environmental journalism and urban or metropolitan life has to be understood not just as a fact of production, but also as an onward negative effect of the industry. Thoreau drew public attention to that complicity at the same time that he used the medium that it made possible. 'Ktaadn' includes a polemic on the destruction of the white pine forests of New England, drawing attention once again to the industrial processing of lumber by sawmills:

The white-pine tree on the shore of Chesuncook . . think how it stands with it now, - sold, perchance, to the New England Friction-Match Company! There were in 1837, as I read, two hundred and fifty saw-mills on the Penobscot and its tributaries . . and they sawed two hundred millions of feet of boards annually. ${ }^{\mathrm{xi}}$

While 'environment' is a word frequently used in the transatlantic periodical press from the 1760 s, it was not until the second half of the nineteenth century that it was connected with the land in itself, or with anything that might be regarded as ecological in a modern sense. Until then, 'environment' was a noun most often used to denote human architectural and social contexts. One of the earliest uses of the term to denote natural surroundings that have an agency in their own right occurred in an article about New York published in the London 
press in 1854, when Chambers's Journal of Popular Literature, Science and Arts included an essay 'Things as they are in America' that describes 'Manhattan, so formed by this environment of water. ${ }^{\text {xii }}$ In its 1857 report on the transatlantic cable, Chambers's again refers to a maritime environment that shapes human lives and progress in technology, when it informs readers of the benefit to communication made possible by the disjunction between turbulent surface and calmer ocean-bed currents: 'In the profound recesses of the Atlantic, there is no violence, and scarcely any motion ... The Atlantic cable will have the softest conceivable environments, for nothing is more tranquil and calm than still water' xiii Working with nature rather than against its forces is identified here as the most efficient way toward more interconnected transatlantic relations.

Although the concept of a climate and geology that affected life forms in a particular area had been current in European natural science from the middle of the eighteenth century, 'environmental' was not explicitly used as an adjective in British and North American periodicals until an 1873 review for The Academy (1869-1902) of a new, revised edition of James Smith and James Sowerby's multi-volume English Botany, originally published between 1790 and 1814. In the North American press, the first notable adjectival use of 'environmental' was in an 1881 essay by palaeontologist S. W. Ford that made connections between trilobite fossils and the rocks in which they were found, published in the American Journal of Science (1880-1910). Ford locates changes in the embryonic stage of the trilobite that look forward to later genetics, as well as acknowledging Darwin's principle of natural selection and earlier theories about environmental adaption:

the remarkable intersection of differential characters ... appear to me to point to the Embryo as the principle theatre of organic evolution in general. It seems ... 
absurd to ascribe such effects [merely] to natural selection, or the influence of environmental conditions. ${ }^{\text {xiv }}$

The term 'naturalist,' however, had been in commonplace use since the middle of the eighteenth century, and 'botanist' featured from an earlier date, appearing in many publications during the seventeenth century.

Difference and monstrosity

How did periodicals use language and compositional techniques to mediate interest in environmental issues? The language and discursive practices of early nineteenth-century environmental journalism tended to compare strange or monstrous natural features and life forms with what was familiar, concentrating on continuums and similarities over fragmentation. Theresa Kelly has investigated the politics of representing botanical exceptions to this rule. ${ }^{\mathrm{xv}}$ Jeffrey Cohen shows how fears of excess in the non-human world, whatever the forms it might take, create a struggle for containment that involves imposing conditions of order, however tenuous. ${ }^{\text {xvi }}$ That excess is more often understood to be rooted in exaggeration and a sense of deformation, along with the transgression of boundaries, than in complete uniqueness. Such a model reverses the conventions of earlier Grand Tour narratives, for example, which as Chloe Chard has said were led by an impulsive need for extravagant exclamation based on 'oppositions between the familiar and the foreign' as a means of "translating foreignness into discourse. ${ }^{\text {xvii }}$ The search for common features nevertheless had its roots in an eighteenth-century Enlightenment impulse towards taxonomic classification that had transatlantic repercussions. Carl Linnaeus (1707-1788) and Georges 
Louis Leclerc, Comte de Buffon (1701-1788) used comparative empirical methodologies to establish classification systems for flora and fauna. They looked for similar species in different continents, drawing conclusions about the extent to which acclimatisation shaped animal and human physiognomy and behaviour. Both Linnaeus and Buffon responded to Montesquieu's argument in De l'esprit des lois that life forms, including humans, responded by adapting to their surroundings. While Linnaeus's Systema Naturae, based on the analysis of common features, became established and accepted as the transatlantic standard model for scientific taxonomy, Buffon's rival Histoire Naturelle asserted that North American species were smaller, less hardy and even degenerate variants of their Northern European counterparts. Buffon continued to draw criticism on the American side of the Atlantic well into the nineteenth century. In an 1815 article about the establishment of the Boston Linnaean Society, the monthly North American Review challenged his credibility on the basis of his anti-Linnaean position on taxonomy, arguing that he had 'hazarded his great reputation' by a 'derogatory response to the methodological arrangement which had been approved by all who were devoted to natural science. ${ }^{\text {xviii }}$ The American Journal of Science and Arts published in 1834 J. H. Griscom's translation of J. H. Fee's Life of Linnaeus, in which the Swedish naturalist's style of writing is described as blending scientific discourse with a more literary, creative style in its 'rapid recital, precise, full of fact, with occasional flashes from the fire of a poetic imagination. ${ }^{\text {xix }}$ Griscom's biography attributed half a century of progress in botanical science 'in a great measure to the influence of Linnaeus,' arguing that the Linnaean systematics had elevated the nomenclature of life forms from a condition of 'disorder, anarchy and embarrassment' into a comprehensible science that anyone could understand ${ }^{\mathrm{xx}}$ Buffon is mentioned in that article only briefly as an antagonist of Linnaeus, while Joseph Banks, John White, and a pan-European group of other renowned explorers are identified as participants in a Linnaean network of knowledge. 
In articles about the natural world that were written before science had considered the historical separation of earth's prehistoric landmasses into modern continents, or begun to think meaningfully about natural selection in the Darwinian sense, questions were nevertheless being asked within and beyond the scientific community about the variety and distribution of the world's flora and fauna. Reviewers responded to those questions. The 1818 review of Humboldt's Researches in the Boston-based Atheneum focuses on attention to the commonality of plant variants as an appropriate way of thinking about nature for botanists and for general readers: 'it is not the contrast, so much as the consent, of all plants of the same genus ... to which we would gladly turn the observation, not only of our botanical readers, but of everyone, who is fond of flowers. ${ }^{x x i}$ This and other reviews take a Romantic position on Humboldt's ideas about ecology, attending to a world where natural sympathy connects not only plants of a common genus growing in different continents, but also specialist and non-specialist readers, who are encouraged to share mutual ground for understanding.

The North American press published notable other reviews of Humboldt's travels. Looking back on his achievement and evaluating his success with general readers, The Literary World in 1849 argued that he had 'united the eye of the artist with the judgment of the philosopher, and loved nature with the faith of childhood, while searching her mighty secrets. ${ }^{\text {xxii }}$ The reviewer shows how Humboldt made comparisons between the pampas and llanos of South America and the plains of North America, in a process that we might today refer to as forensic botany, suggesting that the vegetation of North America 'recall[s] the dried bed of a former ocean.' By comparison, the Amazon forest remained unreadable, because likened by Humboldt to 'a trackless wilderness.' A year later, The Southern Quarterly Review echoed the Edinburgh's tribute to Humboldt as an all-round naturalist, explorer and polymath whose 'great learning and ingenuity' combined understanding in 
astronomy, physiognomy and botany as well as in statistics, political economy, metaphysics, antiquarianism, philology and philosophy:

[He] plucked the alpine flower ... with the eager delight of the botanist . . . explored the animal world in its multifarious forms, with the discrimination of the zoologist ... the skill of the chemist ... [and] considered all things in order to produce a comprehensive philosophy ... of modern science. ${ }^{\text {,xiii }}$

Frameworks such as these for circulating and promoting knowledge converted fear of monstrosity into a pleasurable curiosity. Strategies of containment allowed regulated, distanced glimpses of environments that were, above all, exciting. Furthermore, extension of the everyday and familiar, as a category for understanding landscapes as well as deeper topographies and geologies, was itself heavily dependent on the circulation of printed media: most readers would never see the pampas or llanos, but they could be imagined through the circulation of poetry, fiction, published travel journals, letters, and illustrations made accessible through the periodical press.

Beyond the natural science topics addressed, environmental information was shaped by assumptions about the political positions of particular publications. Looking back to the late eighteenth century, British examples included the Gentleman's Magazine and Monthly Review, both of which regularly featured articles on botany and natural history as part of their attention to Enlightenment science. As Theresa Kelley points out, by the middle of the 1790 s the well established Gentleman's Magazine gave those articles a notably anti-Jacobin and pro-establishment gloss, whereas the Monthly Review used reviews of books on natural 
science to establish sympathy for the principles of the French Revolution. ${ }^{\text {xxiv }}$ Joseph Johnson's Anglo-American team of contributors for the Analytical Review, which included Joseph Priestley, Joel Barlow, Mary Wollstonecraft, William Godwin and Henry Fuseli, focused attention on publications about natural sciences including medicine, anatomy, and botany. Priestley's own work on climate, most notably his Experiments and Observations on Different Kinds of Air, which was reviewed in the Analytical, associated enquiry about the seen and unseen natural world with political freethinking: if readers could think objectively and with self-knowledge about their bodily relation to the physical world around them, they could similarly think critically about their relationship to the nation's political environment. Johnson published, distributed and sold in his St. Paul's Churchyard bookshop all of Priestley's major works. He also published Erasmus Darwin's nature poetry including the two-volume Botanic Garden, Zoonomia and The Temple of Nature, bringing to the public some of the most important early works that conjectured a process of evolution. His imprisonment in 1798 for seditious circulation of printed material ended the Analytical Review's role as a forum for reform-minded, mainly middling-class interest in natural science, but he continued to publish books on scientific topics that were reviewed in other periodicals. I have shown elsewhere how the Crown prosecution made clear that the radical, transatlantic editorial policy of the Analytical, including its encouragement of freethinking through environmental awareness, was the real reason behind Johnson's persecution. ${ }^{\mathrm{xx}}$

On both sides of the Atlantic, half a century after the initial publication of Linnaeus's and Buffon's theories, arguments over those natural scientists' relative merits continued in the periodical press. Meanwhile, Erasmus Darwin's poems popularised not only natural science but also the politics of environmental representation at the turn of the nineteenth century. Of the two parts of Darwin's Botanic Garden, the second volume, The Loves of the Plants, attracted more controversial reviews than the first, The Economy of Vegetation. 
Darwin's allusions to promiscuity in plants' sexual lives were underscored by Linnaeus's classification according to the number and arrangement of a plant's reproductive organs. But where Linnaeus' prose was conventional to Enlightenment scientific treatises, and therefore acceptable, Darwin's allegories of plant sexuality encouraged readers to think in more sensual ways.

The controversy extended across the Atlantic. Reviewing both volumes of The Botanic Garden in June 1802, The New England Quarterly Magazine celebrated Darwin's original use of form, language and taste in the cause of extending natural understanding, commenting that his poem 'favoured the world' by uniting 'the most intricate objects of nature and art' through the exercise of an 'imagination wild and terrific. ${ }^{\text {xxvi }}$ The suitability of literature and the agency of such an exuberant imagination for writing about the environment are established when the reviewer links Darwin's ‘intimate knowledge of every branch of science and natural history' with the 'scripture, ancient mythology, gothic superstition and philosophy' that imbues his 'history of plants ... with life and vigour.'

By comparison, the politically conservative but literarily adventurous Blackwood's Edinburgh Magazine in 1819 accused Darwin of using an 'ill chosen plan' to express 'chimerical notions . . . hazarded on subjects of science,' especially where plants were concerned. ${ }^{\text {xxvii }}$ Yet despite its censure, Blackwood's celebrated Darwin's description of the Nile crocodile not just for its expression of grandeur and sublimity in the animal itself, but because that convention of sublimity could be invoked to guide readers' response to a natural environment much more contentious than Egypt: the pre-historic world. The crocodile enables readers to contemplate 'the production of some of those huge animals with which nature teemed at a remote era [and] whose exuviae embedded them in rocks.' Blackwood's published that review eight years after amateur paleontologist Mary Anning discovered the 
first known fossil of an ichthyosaur at Lyme Regis, providing evidence of the existence of a world very different from that of Regency England.

Travel and environmental journalism

More than a third of the articles published during Francis Jeffrey's twenty-six-year editorship of the Edinburgh Review reviewed narratives of tourism or exploration. ${ }^{\text {xxviii }}$ Most paid some attention to environmental issues, with discursive treatments of geology, flora, fauna and climate. From its inaugural number in October 1802, the Edinburgh Review established a position with which readers would become familiar. Jeffrey's own review of Alexander Mackenzie's Voyages from Montreal . . to the Frozen and Pacific Ocean, in the years 1789 and 1793 argued 'There is something in the idea of traversing a vast and unknown continent . . . the imagination is insensibly engaged and inflamed by the spirit of adventure, and . . a voyage of discovery. ${ }^{\text {xxix }}$ By bringing into the homes of readers the experiences of explorers in regions that most people would never visit - arctic Canada in the case of Mackenzie's Voyages - armchair exploration became a passion that could either underpin or challenge the politics of colonialism. Furthermore, narratives of colonisation need to be read for their treatment of non-human migration by plants, animals, and the agents of disease such as cholera. ${ }^{\mathrm{xx}}$

In December 1814, a month after its review of Williams's translation of Humboldt's Researches, the Edinburgh published William Playfair and geologist Webb Seymour's review of the 1804 to 1806 journals of Lewis and Clark's expeditionary team. Those who made the journey across the American West were represented to readers as 'a band of active and intrepid men, which no country in the world would not be proud to acknowledge ${ }^{\text {xxxi }}$. Such rhetoric implies an independent spirit of adventure that exceeds the boundaries of 
nationalism and from which 'no country' is excluded, suggesting a transnational counterbalance to more exceptionalist readings of the journals (the expedition, after all, was a US government project). Moreover, by emphasising the many moments of excitement and wonder that occur throughout the journal, the review distinguishes scientists primarily interested in discovery from the expansionist political strategies upon which such expeditions were invariably founded, and in which 'the United States seem no less ambitious of expanding their territories than the country from which they sprang.' Kevin Hutchings has shown how indigenous North American writers used the periodical press to represent the natural environment as a site of resistance both to Eurocentric and Anglo-American nationalism, as in the example of Ojibwe poet William Wilson's contributions to the Toronto based Christian Guardian. ${ }^{x x i i}$

Specialist natural science magazines had been in circulation from at least the late eighteenth century, but by the middle of the 1820 s demand led to many more entering the marketplace. Publications produced in Britain and North America were read on both sides of the Atlantic, establishing communities for understanding the natural world. Scottish botanist, member of the Zoological Society of London, plant collector and journalist Charles Loudon founded The Gardeners Magazine and Register of Rural and Domestic Improvement (18261844), after publishing earlier essays on civic landscaping that influenced the planting of trees in London's streets according to a natural system, with species named for the benefit of public education. Carrying articles and letters from readers about botanical collecting and horticulture, The Gardener's Magazine challenged Walter Scott's claim that Canadian pines were being planted in place of Scots pines because of their faster growth. Scott's anxiety had been made public in his review of Robert Monteath's The Forester's Guide and Profitable Planter for the Quarterly Review in October $1827{ }^{\text {xxiii }}$ He was indeed wrong, but his concern was visionary: within a few years, Douglas Fir and Sitka Spruce became overwhelmingly the 
most commonly planted species in British commercial forestry, for reasons that he had given: their fast growth produced better financial returns. Meanwhile, Loudon also founded and edited The Magazine of Natural History and Journal of Zoology, Botany, Minerology, Geology and Meteorology, published in London from 1829-1837. Editorship was taken over in 1836 by palaeontologist Edward Charlesworth, a correspondent with Charles Lyell, and the name changed a year later to the simpler and more popular title The Magazine of Natural History. A further name change in 1841 to The Annals and Magazine of Natural History established one of the most important environmental periodicals of the middle of the nineteenth century, globally as well as transatlantically. A scientific publication that appealed to both a specialist and general readership in Britain and in North America, the magazine's significance lies in its September 1855 publication of Alfred Russell Wallace's 'On the Law which has Regulated the Introduction of New Species.' Lyell's concern about Wallace's article directly led Charles Darwin towards his 1859 publication On the Origin of Species. It would be impossible in a chapter of this length to address the volume of response to Charles Darwin's publications in the periodical press, so acknowledgement that the controversy would continue throughout the rest of the century and beyond must suffice.

Later in the century, a number of specialist magazines emerged that expanded transatlantic networks of environmental journalism. Forest and Stream was founded by professional journalist, editor, agriculturalist, and hunter Charles Hallock in 1873 and later edited by George Grinnell. Promoting conservation as part of North American cultural identity, Forest and Stream became the main medium of circulation for the Audubon Society. Regular columnist George Washington Sears popularised an outdoors lifestyle that included accounts of his exploration by canoe of the Adirondacks, with information on animals, birds, fish and tree species. Sears was an important transatlantic journalist not least because his writing reconnected with the North American folkloric figure of the trapper and 
backwoodsman, familiar to readers through literary works such as the Leatherstocking novels by James Fenimore Cooper, themselves influenced by Walter Scott's fiction. Sears's own inspiration - the Scottish lawyer, explorer and travel writer John 'Rob Roy' MacGregor was nicknamed after Scott's fictional treatment of the legendary highlander. The transatlantic literary network within which Sears's columns participated also included Scots journalist and novelist Robert Louis Stevenson who, before his journey to North America and the writing of The Master of Ballantrae (1889), which reaches its conclusion in the wilderness of northern New York State, published his own counterpart to Sears's column in his first book, An Inland Voyage, a recording of his 1876 journey of exploration in a 'Rob Roy' canoe through the canals and inland waterways of France and Belgium. Garden and Forest: a Journal of Horticulture, Landscape Art, and Forestry (1888-1897), begun and edited by Charles Sprague Sargent, the founding director of Harvard's Arnold Arboretum, was the first North American magazine dedicated to conservation science and the nation's forests. In particular, Garden and Forest explored the impact of public interest in wilderness environments at the same time that it shaped the beginnings of a conservation movement. Many of these publications privileged hunting and outdoor lifestyles as a return through leisure activities to a simpler way of life. It is tragic that interest in conservation grew in decades during which the North American bison was almost rendered extinct by hunting and habitat loss, and in which the passenger pigeon was extirpated in the wild. The last passenger pigeon died in a Cincinnati zoo in $1914 .^{\text {xxxiv }}$

So far, only one Canadian periodical has featured in this chapter. ${ }^{\mathrm{Xxxv}}$ Canada's contribution to transatlantic environmental journalism began with numerous short-lived publications that from the late eighteenth century addressed matters including exploration of the northern territories, emigration, colonial and local politics, trade including the fur and lumber industries, missionary activity and relations with indigenous people. The number of 
publications makes it impossible to provide a sufficient overview, but it is perhaps appropriate to look at the Canadian Illustrated News, published in Montreal by George Desbarats from 1869 until 1883. The Canadian's most significant innovation was its use of photoengraving to reproduce half-tone photographs. While that method would be superceded in the 1880 s by rotogravure, the publication of photographic plates established new ground in the relationship between text and image. Plates of public figures and of scenery made explicit connections between the Crown, colonial political economy and Canada's natural environment. The 1869 cover of the Canadian's first number carried a photoengraving of Prince Arthur, who had just accepted the Iroquois title of Chief of the Six Nations. He would be Governor General of Canada from 1911 until 1916. That initial image shows Prince Arthur wearing military uniform, but a more conventional woodcut in 1870 , titled 'H. R. H. Prince Arthur as an Axeman,' depicts him felling a large tree. ${ }^{\text {xxxi }}$ The scale of the nineteenthcentury Canadian lumber industry is well documented, and that symbolic participation by a representative of the Crown endorsed a cultural identity that is comparable with the figure of the backwoodsman in the United States. Indeed, the promotion of a land whose vast natural environment could be imagined in terms of an integrated economy of timber, grain production and fishing was a constant theme throughout the fourteen-year lifetime of the Canadian Illustrated News. Another article in the inaugural issue by the Reverend A. E. Dawson of Ottawa titled 'The North-West Territory: the Extreme North' argued that areas west of Newfoundland and Labrador and up to $65^{\circ}$ North could be developed for grain farming to 'afford valuable resources to the trading population,' while 'the fisheries of the McKenzie River itself in connexion with the sea fisheries are capable of being developed.' The same column predicted a mineral extraction industry that would remain controversial to the present day, with its identification of a 'mass of minerals' including 'deep beds of bituminous shales, associated with alum and beds of iron clay' as well as soil rich in 'mineral 
tar. ${ }^{\text {xxxvii }}$ This interpretation of the non-human world according to economic models and industrial processes demonstrates how far the late nineteenth-century scientific and popular imagination was driven by a desire to consume both resources and knowledge.

I have argued for the emergence of a dynamic transatlantic environmental journalism across the nineteenth century by looking at examples taken from a range of writing and from different types of periodical. My aim has been to look beyond what is already well known, at the diverse ways in which understanding of the non-human world was shared among scientists, journalists and the general population. Some canonical figures who would feature prominently in a book-length study have not been treated. Others have only been mentioned in passing. The sizeable body of scholarship that looks in detail at periodical writings by, for example, George Lyell, Ralph Waldo Emerson, Henry David Thoreau, John Muir, and Charles Darwin, is better positioned to assess the complexity of their contributions to a transatlantic environmental imaginary. The ocean provided a locus for writers who were emigrants or were born into emigrant families, a means of physical and intellectual exploration for travellers between North America and Europe, a forum for reception and debate for those whose writing circulated across and around its perimeters, and a medium for the transmission of new technologies for viewing and comprehending natural science. In accordance with David Armitage's vocabulary of Atlantic studies, the context considered is transatlantic because internationally comparative and concerned with dialogue beyond national boundaries, circum-Atlantic in its attention to a migratory history of ideas that grew around the ocean's shores to make possible mobile intellectual communities, and cis-Atlantic through its concern with the relationship of particular places and locations within a wider web of connection. ${ }^{\text {xxxviii }}$

Perhaps the most significant feature of writing about the environment in transatlantic nineteenth-century journal culture was the manner in which the production, reception and 
circulation of knowledge about the natural world became democratised: contributors to the periodical press did not necessarily need the formal scientific training or higher education that mostly lay behind eighteenth-century discourses on natural topics. Ojibwe poet John Wilson's view of Niagara and the letters written by women travelling for the first time without male chaperones reacted to earlier writing in the review and magazine press about the land and nature, but the addition of their understanding contributed to the transmission of knowledge. In this respect, early environmental journalism participated in a very modern development of race and gender equalities that is still unfolding through social media on the twenty-first-century Internet.

The nineteenth century began with echoes of Linnaeus, Buffon, Banks, Cook, and Humboldt along with other key scientists and explorers who were shapers of a public environmental imagination. However, exploration and its role in knowledge production are notoriously complicit in imperial and colonial agendas, which is why the final case study here of The Canadian Illustrated News shows how a popular newspaper represented the abundance of the non-human world in terms of its potential to generate wealth for the nation. In the same years, big blue stem grass and the flowers of the tall grass prairie were being replaced by wheat, barely, and oats while commercial forestry was replacing old growth trees. North America had opened national parks including Yellowstone in 1872 and Yosemite in 1890 as places that a public with means to travel could see a preserved natural world, while much of the rest of that extended world was rapidly being exploited by agricultural and industrial production. John Muir's journalism played a key role in promoting the parks' centrality to the conservation movement. In Britain, the United States and Canada field sports magazines catered for readers who did not physically need to participate in those pursuits in order to image themselves as part of an environmentally conscious movement. Meanwhile, the Audubon Society's first magazine, which called for the preservation of birds during a 
time of intensive interest in hunting and commercial marketing of avian products, was produced by George Grinnell (mentioned above as editor of Forest and Stream) in 1887, only to fail financially after just two years. A longer study would explore Audubon founding activists Harriet Hemenway and Minna Hall's campaign against the use of feathers and stuffed birds in women's clothing, publicised through the pages of fashion magazines including Harper's Bazaar. ${ }^{\text {xxix }}$

The nineteenth century reveals conflicting anxieties about changes to land use and the distribution of species, as well as to the circulation of knowledge. While the humanities and sciences were interrelated areas of enquiry in 1800 , by the end of the century cellular biology was producing specialized understanding of a natural environment too small for the eye to see. People wanted to know about those developments, but were dependent upon the media of representation. As always, editors and contributors had considerable control over what was made public and the forms that information took. Looking back from a twenty-first-century perspective, the creation of a nineteenth-century public domain for discussion established a space for holding to account how the language and interpretation of environmental knowledge was used. Not everyone was represented. Dissent could have disastrous consequences for those who mounted critiques. Journals, magazines and newspapers still have an important role to play in keeping such contentious spaces accessible and democratic. The present study began and ends with questions. Where do the boundaries of 'environmental journalism' lie, and is there a clear line of development that can be traced to contemporary participation of the periodical press in ecological concerns that are transatlantic as well as more global?

\section{Susan Oliver}


Notes

${ }^{\mathrm{i}}$ William Henry Fox Talbot, The Pencil of Nature (London: Longman, Brown, Green and Longmans, 1844), p. 27.

ii The Lancet, 1:1, 25 September 1830, p. 1.

${ }^{\text {iii }}$ Monthly Review, or, Literary Journal, 27, October 1798, p. 140.

iv Ibid. p. 136.

${ }^{\mathrm{v}}$ For theories linking the Anthropocene to steam power, see Dipesh Chakrabarty, 'The Climate of History: Four Theses,' in Critical Inquiry 35:2, 2009, pp. 197-222; Timothy Morton, Hyperobjects: Philosophy and Ecology after the End of the World (Minneapolis: University of Minnesota Press, 2013). For the theory of urbannature see Ashton Nichols, Beyond Romantic Ecocriticism: Toward Urbannatural Roosting (New York: Palgrave Macmillan, 2011).

${ }^{\mathrm{vi}}$ Lance Newman, Our Common Dwelling: Henry Thoreau, Transcendentalism, and the Class Politics of Nature (Basingstoke: Palgrave Macmillan, 2005), p. 56. Annette Kolodny, The Lay of the Land: Metaphor as Experience and History in American Life and Letters (Chapel Hill: University of North Carolina Press, 1975). Cited Newman.

${ }^{\text {vii }}$ L. Bischof, ‘A Summer in England: The Women's Rest Tour Association of Boston and the Encouragement of Transatlantic Travel for American Women,' in Beth L. Lueck, Brigitte Bailey, and Lucinda L. Damon-Bach (eds), Transatlantic Women (Durham: University of New Hampshire Press, 2012), pp. 153-71.

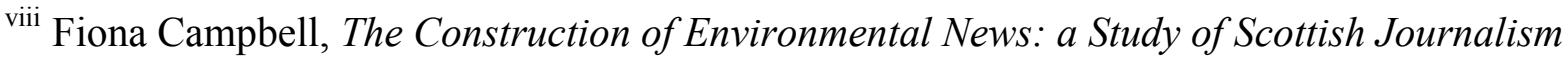
(Aldershot: Ashgate, 1999), p. xi. 
${ }^{\text {ix }}$ Michael Frome, An Introduction to Environmental Journalism (Salt Lake City: University of Utah Press), pp. 2, 94.

${ }^{\mathrm{x}}$ Ibid. 24.

${ }^{\text {xi }}$ Henry David Thoreau, 'Ktaadn, and the Maine Woods: the Wilds of Penobscot,' The Union Magazine of Literature and Art, 1:29, July 1848, pp. 29-30.

${ }^{x i i}$ Chambers's Journal of Popular Literature, Science and Arts, 22, 3 June 1854, pp. 321-42. xiii Ibid. 182, 27 June 1857, p. 403.

${ }^{\text {xiv }}$ S. W. Ford, 'On additional Embryonic Forms of Trilobites from the Primordial Rocks of Troy, N. Y.,' American Journal of Science, 22: 1, 30 October 1881, p. 250.

${ }^{\mathrm{xv}}$ Theresa Kelley, Clandestine Marriage: Botany and Romantic Culture (Baltimore: Johns Hopkins University Press, 2012), pp. 17-51.

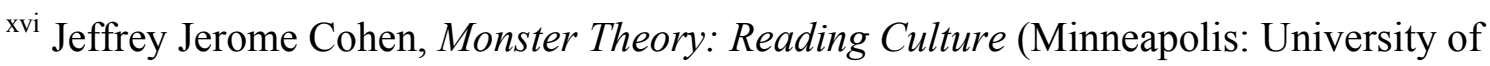
Minnesota Press, 1996), p. 6.

${ }^{\text {xvii }}$ Chloe Chard, Pleasure and Guilt on the Grand Tour (Manchester: Manchester University Press 1988), pp. 4, 238-9.

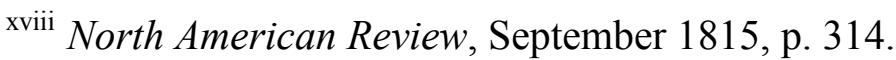

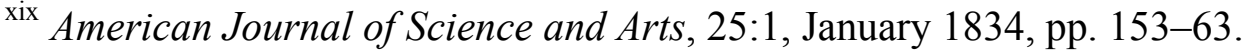

${ }^{\mathrm{xx}}$ Ibid. p. 160.

xxi Atheneum 3:9, August 1818, p. 336.

xxii The Literary World, 3 November 1849, p. 377. 
xxiii Edinburgh Review, 24:47, November 1814, 145. The Southern Quarterly Review, 1:1, April 1850, p. 160.

${ }^{\text {xxiv }}$ Kelley, p. 64.

${ }^{\mathrm{xxv}}$ Susan Oliver, 'Silencing Joseph Johnson and the Analytical Review,' The Wordsworth Circle, 40.2-3, 2009, p. 101.

${ }^{x x v i}$ The New England Quarterly Magazine, 2:1, June 1802, p. 193.

xxvii Blackwood's Edinburgh Magazine, 5:26, May 1819, pp. 153-4.

xxviii Massimiliano Demata, 'Prejudiced Knowledge: Travel Literature in the Edinburgh Review,' in Massimiliano Demata and Duncan Wu (eds) British Romanticism and the Edinburgh Review (Basingstoke; New York: Palgrave Macmillan, 2002), pp. 82-101.

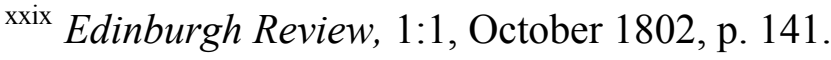

${ }^{\mathrm{xxx}}$ See Susan Oliver, 'Contagion and the City: Writing Boston as a Transatlantic City in the Early Nineteenth Century,' in Jonathan White and I-Chun Wang (eds), The City and the Ocean: Journeys, Memory, Imagination (Newcastle-upon-Tyne: Cambridge Scholars Publishing, 2012), pp. 60-74.

${ }^{x x x i}$ Edinburgh Review, 24:48, February 1815, p. 438.

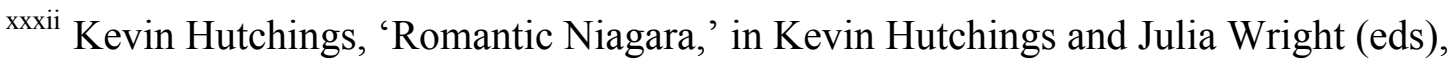
Transatlantic Literary Exchanges, 1790-1870: Gender, Race, and Nation (Farnham; Burlington: Ashgate, 2011), pp. 158-9.

${ }^{x x x i i i}$ Quarterly Review, 36:72, October 1827, pp. 558-600. Susan Oliver, 'Planting the Nation's "Waste Lands": Walter Scott, Forestry and the Cultivation of Scotland's Wilderness,' in Literature Compass 6:3, 2009, pp. 585-98. 
${ }^{\text {xxxiv }}$ For one of the best literary reflections of the extinction of the passenger pigeon, see Aldo Leopold, A Sand County Almanac and Sketches Here and There (Oxford: Oxford University Press, 1949), p. 12.

${ }^{\text {xxxv }}$ My forthcoming book, Arbiters of Opinion: Transatlantic Periodicals 1790-1860 will look in more detail at Canadian journalism.

xxxvi The Canadian Illustrated News 1:1, 30 October 1869, Cover; 1:12, 22 January 1870.

Library and Archives Canada, <http://www.bac-lac.gc.ca/eng/discover/canadian-illustratednews-1869-1883/Pages/canadian-illustrated-news.aspx $>$ (last accessed 18 September 2015). A disclaimer states: 'The illustrations and articles in Canadian Illustrated News reflect the views of the artists, authors, and editors of the newspaper and represent the era in which they worked. These views are by no means those of Library and Archives Canada.' xxxvii Ibid.

xxxviii David Armitage, 'Three Concepts of Atlantic History,' in Armitage and Michael J. Braddick (eds), The British Atlantic World 1500-1800 (Basingstoke; New York: Palgrave Macmillan, 2002), pp. 17-27.

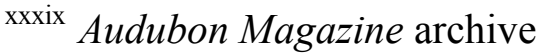
$<$ http://archive.audubonmagazine.org/features0412/hats.html $>$ (last accessed 18 September 2015); 'Feather trade, feather adornment, hunting and collecting,' Smithsonian Magazine $<$ http://americanhistory.si.edu/feather/ftam.htm $>$ (last accessed 18 September 2015). 